\title{
Two heads are better than one? Assessing the implications of the \\ Conservative-Liberal Democrat coalition for UK politics
}

Political Science 63(I) 45-60

(C) The Author(s) 2011

Reprints and permissions: sagepub.co.uk/journalsPermissions.nav DOI: I0.I I77/00323 I87 I | 404532 pnz.sagepub.com @SAGE

\section{Elizabeth Evans}

\begin{abstract}
The Westminster model is recognized the world over as delivering strong, stable one-party government with hung parliaments an anomaly. The recent UK general election has proved the exception to the rule, with 2010 providing the first hung parliament since 1974. Unlike the 1974 minority administration, 2010 saw the formation of a coalition government for the first time in over 70 years. Bringing together the Conservatives and Liberal Democrats, two parties not seen as natural bedfellows, the coalition has proven somewhat of a political experiment. While the coalition may have surprised many, this article highlights how the UK's shifting political landscape and changes in personnel at the top of both parties has facilitated the coalition. In doing so the article questions how the coalition will impact upon the Liberal Democrats in particular, and explores the extent to which coalition governments might constitute a more permanent feature in UK politics.
\end{abstract}

\section{Keywords}

coalition, Conservatives, Liberal Democrats, UK

\section{Introduction}

The Westminster model is characterized by the delivery of strong and cohesive single-party majority government. ${ }^{1}$ This stable model of government is supported by a two-party system

\section{Corresponding author:}

Elizabeth Evans, Department of Politics and International Relations, School of Social Sciences, Kingston University, Kingston upon Thames, KTI 2EE, UK

Email: elizabeth.evans@kingston.ac.uk

1 A. Lijphart, Patterns of Democracy (New Haven, CT: Yale University Press, 1999). 
that has, until recently, tended to ensure the regular alternation of government between the two biggest parties, the Conservatives and Labour. The 2010 UK general election, however, resulted in the formation of the first peacetime coalition since the $1930 \mathrm{~s}$. This was, moreover, a coalition between the centre-right Conservatives and centreleft Liberal Democrats, two parties with seemingly little in common. The election has inevitably challenged prevailing assumptions about the design and utility of the UK's electoral and party system and also raised questions about accountability and the legitimacy of an elite-driven coalition formation process. Many commentators expressed surprise that no one party won an overall majority and that a coalition was formed between two very different parties. This article argues that changes in personnel and direction in both parties, coupled with an electoral system that can no longer be relied on to deliver strong one-party government, ${ }^{2}$ helped facilitate the coalition. Although the coalition has been treated with suspicion in some quarters, it is clear that both parties potentially have a lot to gain from the arrangement.

Theoretical accounts of coalition government formation include analysis of a wide range of underlying factors, including the desire to hold office ${ }^{3}$ a way of advancing specific policy initiatives; ${ }^{4}$ and a sense of patriotic duty during periods of crisis. ${ }^{5}$ Others have sought to highlight the key role played by individuals in forming coalitions, stressing the importance of inter-personal relationships between critical actors within and between political parties. ${ }^{6}$ When considering the formation of the $2010 \mathrm{UK}$ coalition government all of these motivations appear to have played a role, although it is worth stressing from the outset that it was a unique parliamentary situation that gave rise to this coalition. It is also true, however, that ideological shifts within both political parties, combined with reactions to the economic situation and a desire on the part of the Liberal Democrats to establish credibility by participating in government, all helped bring about the coalition.

Following the 1998 devolution settlements, coalitions per se are not a new entity in UK politics, and power-sharing between parties at a local government level is common. In fact, despite the fact that single-party government in post-war Britain has been the norm, there have been a surprisingly high number of occasions when the government has had to depend upon the support or abstention of at least one opposition party. ${ }^{7}$ The best known of these, the 1977-8 pact between Labour and the Liberals (the predecessor party to the Liberal Democrats), was not a formal coalition, and while it was formed during a period of economic crisis, it was, according to Butler, 'born of parliamentary tactics

2 J. Curtice, 'So What Went Wrong with the Electoral System? The 2010 Election Result and the Debate about Electoral Reform', Parliamentary Affairs, vol. 63, no. 4 (2010), pp. 623-38.

3 W. H. Riker, The Theory of Political Coalitions (New Haven, CT: Yale University Press, 1962).

4 R. M. Axelrod, Conflict of Interest: A Theory of Divergent Goals with Application to Politics (Chicago: Markham Publishing Company, 1970).

5 D. Butler (ed.), Coalitions in British Politics (London: Macmillan, 1978), p. 113.

6 H. Bäck 'Intra-Party Politics and Local Coalition Formation', in D. Giannetti and K. Benoit (eds), Intra-Party Politics and Coalition Governments (London: Routledge, 2009), pp. 53-68.

7 Butler, Coalitions in British Politics, p. 113. 
rather than national necessity ${ }^{8}$ Notwithstanding a brief period towards the end of John Major's Conservative government, 1996-7, when he had to rely on the support of the Ulster Unionists, single-party government at Westminster has marked the years since $1979 .{ }^{9}$

While the 2010 general election was the first to produce a hung parliament since February 1974, close inspection of electoral patterns over the past 30 years reveal that the chances of a hung parliament were in fact increasing. Before considering coalition formation and the impact of the coalition on the political parties, and also exploring the implications of the arrangement for UK politics more broadly, it is worth explaining why the 2010 general election resulted in a hung parliament. In doing so the article asks whether coalitions might become a more regular feature of Westminster government.

\section{The 2010 general election campaign and results}

Scholars have thus far been in broad agreement that the 2010 general election marked a watershed in British politics. Indeed the election has been notable for a number of reasons: it resulted in the first peacetime coalition for more than 70 years; televized leaders' debates occurred for the first time; and it took place within the context of a world financial crisis and the shadow of the parliamentary expenses scandal that had seriously damaged public confidence in Westminster. ${ }^{10}$ The political landscape in the run up to 2010 had also shifted: none of the three party leaders was in situ at the last general election; the expenses scandal had led to a high number of incumbents standing down; and various leading newspapers had switched their allegiance away from Labour to either the Conservatives or the Liberal Democrats. ${ }^{11}$ All of these factors meant that the 2010 election would be closely fought.

In principle 2010 should have provided propitious circumstances for the Conservatives to return to government after 13 years in opposition. Labour under Gordon Brown appeared fatigued and he was routinely attacked in the press whilst fire-fighting against attempted coups within his own party. But while David Cameron had undeniably revived and 'decontaminated' the Conservative brand, it was clear that he had not done enough to overcome the lack of public trust in the party. ${ }^{12}$ Moreover, the legacy of the Labour landslide in 1997, and the subsequent poor electoral performances from the Conservatives at the following three elections, meant that Cameron faced an uphill battle to win the extra 128 seats needed to form a majority government. ${ }^{13}$

The Conservatives fought the election campaign promising to cut the deficit and to protect the National Health Service (NHS). These messages were largely successful,

8 Butler, Coalitions in British Politics, p. 110.

9 V. Bogdanor, The New British Constitution (Oxford: Hart Publishing, 2009), p. 122.

10 D. Kavanagh and P. Cowley, The British General Election of 2010 (Basingstoke: Palgrave, 2010).

11 A. Geddes and J. Tonge, 'How Britain Got Hung', Parliamentary Affairs, vol. 63, no. 4 (2010), pp. 583-87.

12 T. Bale and P. Webb, 'The Conservative Party', in N. Allen and J. Bartle (eds), Britain at the Polls 2010 (London: Sage, 2010), pp. 37-62.

13 At present 326 seats are need to secure an overall majority in the House of Commons. 
although Cameron's 'Big Society' idea was widely criticized as being ill thought through and was interpreted as an attempt to roll back state provisions. ${ }^{14}$ Further 'problematic' policies included a marriage tax allowance which amounted to just $£ 3$ per week and a crackdown on 'benefit cheats', which in practice would have little impact on reducing public spending. ${ }^{15}$ Despite being a clear 8 percentage points ahead in the opinion polls on the day the election was called, the Conservatives were not able to capitalize on this advantage. The party gained 108 seats, but many within it were critical of the way in which the election campaign had been handled. Indeed, research has indicated that the base of Conservative support had stayed roughly equal to that in 1997 when the party suffered their largest electoral defeat. ${ }^{16}$

Opinion polls were favourable for the Liberal Democrats throughout the campaign, as was the media coverage; the hype of 'Cleggmania' dominated much reporting of the campaign. Core platforms for the Liberal Democrats were fairer taxes and cleaner politics. However, the spectre of a hung parliament overshadowed many of the detailed policy debates, with repeated calls from senior Labour politicians for Liberal Democrat supporters to vote tactically in an anti-Conservative alliance. ${ }^{17}$ Nick Clegg appeared to encourage this narrative when on 11 April he called the possibility of a hung parliament a 'good thing'. Yet a sense of ennui permeated reaction to the Liberal Democrat leader's performance in the final TV debates, and, particularly given the media hype, the party's performance at the ballot box was disappointing, with the party's overall share of the vote increasing by just under 1 per cent. There was a suspicion amongst some party activists that the party got carried away and failed to stay on-message effectively. Perhaps more worrying for the party was the fact that geographical variations in support for the party largely mirrored the problems faced by the party at the 2005 election. ${ }^{18}$

The 2010 election results made visible subtle changes that had occurred to the electoral landscape over the past 30 years. These changes, which included the steady decline of the two-party system, meant achieving an outright majority at the 2010 election was a difficult prospect for any party. The UK's First-Past-the-Post (FPTP) electoral system has traditionally resulted in a system of one-party government, alternating between the two biggest parties, an outcome usually credited to an understanding that majoritarian electoral systems tend to favour two-party systems. ${ }^{19}$ Underpinning this assumption is the belief that people are discouraged from voting for minor parties when

14 Bale and Webb, 'The Conservative Party', p. 55.

15 Kavanagh and Cowley, The British General Election of 2010, p. 161.

16 J. Green, 'Strategic Recovery? The Conservatives Under David Cameron', Parliamentary Affairs, vol. 63, no. 4 (2010), pp. 667-88.

17 See, for instance, 'Election 2010: Adonis in Plea to Lib Dems', editorial, The Scotsman, 12 April 2010.

18 D. Cutts, E. Fieldhouse and A. Russell, 'The Campaign that Changed Everything and Still Did Not Matter? The Liberal Democrat Campaign and Performance', Parliamentary Affairs, vol. 63, no. 4 (2010), pp. 689-707.

19 M. Duverger, Political Parties: Their Organisation and Activity in the Modern State (London: Methuen, 1954). 
Table I. Share of the vote in UK general elections, 1945-2010

\begin{tabular}{lccc}
\hline Election & Conservative and Labour (\%) & Liberal/Alliance/ Lib. Dem (\%) & Other (\%) \\
\hline 1945 & 87.6 & 9.0 & 3.4 \\
1950 & 89.5 & 9.1 & 1.4 \\
1951 & 96.8 & 2.6 & 0.6 \\
1955 & 96.1 & 2.7 & 1.2 \\
1959 & 93.2 & 5.9 & 0.9 \\
1964 & 87.5 & 11.2 & 1.3 \\
1966 & 89.9 & 8.5 & 1.5 \\
1970 & 89.5 & 7.5 & 3.0 \\
1974 Feb & 75.1 & 19.3 & 5.6 \\
1974 Oct & 75.1 & 18.3 & 6.7 \\
1979 & 80.8 & 13.8 & 5.4 \\
1983 & 70.0 & 25.4 & 4.6 \\
1987 & 73.1 & 22.6 & 4.4 \\
1992 & 76.3 & 17.8 & 5.8 \\
1997 & 73.9 & 16.8 & 9.3 \\
2001 & 72.4 & 18.3 & 9.4 \\
2005 & 67.6 & 22.0 & 10.4 \\
2010 & 65.1 & 23.0 & 11.9 \\
\hline
\end{tabular}

Source: Adapted from Curtice, 'So What Went Wrong with the Electoral System?', p. 626.

they realize that there is a low likelihood of minor parties either gaining seats or forming government in an FPTP system.

Despite the electoral system, however, and as the data in Table 1 illustrates, there has actually been a marked decrease in the share of the vote for the two main UK political parties, and a notable increase in the share of the votes cast for the Liberal Democrats, their predecessors and other parties. This decline of the two-party system at Westminster has been masked by FPTP's way of translating votes into seats (see Table 2), although it is a trend that has been observed by scholars over the past 30 years. ${ }^{20}$ Importantly, however, it remains a fact that third parties have not been able translate this increased share of votes into a significantly increased share of parliamentary seats.

Despite the fact that the percentage of votes cast for the third party has not translated into many seats, notably at the 1983 general election, the steady gains made by the Liberal Democrats and other parties have had an important impact on the decline of the two-party system. At the 2010 election 86 MPs representing parties other than the main two were returned to Westminster (13.2 per cent). Although seemingly only a small percentage of the House of Commons, this figure is significant, as the decrease in the number of MPs representing either of the two main parties makes it harder for them to achieve an overall majority, therefore increasing the likelihood of a hung parliament. Moreover, as a result of entrenched areas of geographical support for one or other of the two main parties increasing, the overall number of marginal seats has declined.

20 See, for instance, Butler, Coalitions in British Politics. 
Table 2. Number of seats won in UK general elections, 1945-2010

\begin{tabular}{lcccr}
\hline Election & Conservative & Labour & Liberal/Alliance/Lib. Dem & Other \\
\hline 1945 & 210 & 393 & 12 & $25^{\mathrm{a}}$ \\
1950 & 297 & 315 & 9 & 4 \\
1951 & 321 & 295 & 6 & 3 \\
1955 & 344 & 277 & 6 & 3 \\
1959 & 365 & 258 & 6 & 1 \\
1964 & 303 & 317 & 9 & 1 \\
1966 & 253 & 363 & 12 & 2 \\
1970 & 330 & 287 & 6 & 7 \\
1974 Feb & 297 & 301 & 14 & 23 \\
1974 Oct & 276 & 319 & 13 & 27 \\
1979 & 339 & 268 & 11 & 17 \\
1983 & 397 & 209 & 23 & 21 \\
1987 & 375 & 229 & 22 & 24 \\
1992 & 336 & 271 & 20 & 30 \\
1997 & 165 & 418 & 46 & 29 \\
2001 & 166 & 412 & 52 & 31 \\
2005 & 198 & 355 & 62 & 29 \\
2010 & 306 & 258 & 57 & \\
\hline
\end{tabular}

Source: Adapted from Allen and Bartle, Britain at the Polls 2010, p. 267.

${ }^{a}$ Excludes university seats that were elected on single transferable vote.

This is important because it means that it is harder for the two main parties to win an overall majority when many parts of the country are effectively no-go areas for them: for example, the unpopularity of the Conservatives in Scotland makes it difficult for them to gain seats there. ${ }^{21}$

\section{An unlikely partnership}

Following the election it was far from clear that the Conservatives and Liberal Democrats would form a coalition. The long-cherished dream of realigning the left in British politics, as discussed by Tony Blair and Paddy Ashdown (a former Liberal Democrat leader), meant the automatic assumption was to first examine the possibility of a Labour-Liberal Democrat coalition. The data in Table 2, however, highlights the arithmetical challenge of such a centre-left coalition. Indeed, a 'rainbow' coalition with the various smaller parties would have been required in order to achieve the 326 seats needed for a majority. For the Liberal Democrats, who had long promoted proportional representation, 2010 was an important opportunity to demonstrate the viability of multiparty governance. Moreover, it offered the party an opportunity to participate in government for the first time in 65 years. The combined numbers of Conservative and Liberal Democrat MPs therefore proved an important foundation for the negotiations.

21 Curtice, 'So What Went Wrong with the Electoral System?', p. 635. 
This unlikely partnership was also smoothed by shifts in personnel and approach within the two parties, which had undergone considerable change since the last election. The following section details some of these changes.

\section{Getting to 2010: the Conservatives}

The Conservatives were used to being seen as the 'natural party of government' in post-war Britain. ${ }^{22}$ However, their performance in 1997 saw them suffer their biggest electoral defeat since 1906, and, as the data in Table 2 highlights, the party struggled to make much headway at the subsequent two elections. Adopting at times reactionary policies, they sought to shore up their core vote by playing to the Eurosceptic wing of the party. When David Cameron took over the leadership of the Conservative Party in 2005 he faced a number of difficult challenges: the Conservatives had lost the last three elections; they had failed to create a coherent policy agenda that the public could engage with; the centre ground had been lost to Labour under Blair's stewardship; and, perhaps most importantly, many people simply felt that the Conservatives were out of touch with ordinary people. ${ }^{23}$ Consequently, upon becoming leader it was clear that Cameron needed to make a series of drastic changes if the party were to be rehabilitated in public opinion.

In terms of policy Cameron sought to identify new areas of concern for the party, such as the NHS and the environment. The environment in particular was given a special focus after the party changed its logo from a torch to a tree, signalling their 'vote blue, go green' strategy. This shift in policy focus, coupled with a decision to target the electoral centre, helped Cameron 're-brand' the party. ${ }^{24} \mathrm{He}$ also avoided making specific policy commitments during the long election campaign, although when pledges were made (dropping the rate of inheritance tax, for example), they proved popular with the public. His re-branding of the party was an important step in preparing the Conservatives for government, although it was clear that sections of his own party remained suspicious about the new-look Conservative Party. As such, Cameron sought to reassure the grassroots that he remained a committed Eurosceptic who would be tough on immigration. ${ }^{25}$

One of the key ways in which Cameron sought to illustrate the change within the Conservative Party was by experimenting with various candidate-selection methods in order to ensure that the MPs returned at the 2010 election more closely resembled the country that they sought to serve. For instance, prior to 2010 there were only 17 female

22 T. Bale, The Conservatives: From Thatcher to Cameron (London: Polity, 2010).

23 S. Lee, 'David Cameron's Political Challenges', in S. Lee and M. Beech (eds), The Conservatives under David Cameron (Basingstoke: Palgrave, 2009), pp. 1-9.

24 Bale, The Conservatives: From Thatcher to Cameron; and P. Norton, 'David Cameron and Tory Success: Architect or By-Stander', in Lee and Beech, The Conservatives under David Cameron, pp. 31-43.

25 T. Bale and E. Sanderson-Nash, 'A Leap of Faith and a Leap in the Dark: The Impact of the Coalition on the Conservatives and Liberal Democrats', in S. Lee and M. Beech (eds), The Cameron-Clegg Government: Coalition Politics in an Age of Austerity (Basingstoke: Palgrave, 2011). 
MPs and 9 MPs from ethnic minorities; following the election this rose to 49 and 11 , respectively. ${ }^{26}$ Although it remained the case that the overwhelming majority of Conservative MPs were white men, engaging with selection strategies, such as the creation of a 'priority list' of candidates and the use of open primaries, demonstrated a willingness on the part of the party leadership to try and change the image of the party.

These changes in policy focus for the Conservative Party, coupled with the symbolic modernization process, undoubtedly helped win over Liberal Democrat support for the coalition, not least because of a sense of having been betrayed by Labour concerning constitutional reform. Moreover, since the last election the third party had also undergone a period of transformation, with a new generation of MPs who were not simply content to spend their political careers in permanent opposition.

\section{Getting to 2010: Liberal Democrats}

Since their formation in 1988, the Liberal Democrats have consolidated their third-party status in the UK. They have continued to increase their presence at a local level and have won control of key local authorities in some of the UK's largest cities, while also forming coalition governments with Labour at the devolved level in both Wales and Scotland. The party has also attempted to demonstrate its credibility (where credibility is judged to be adherence to fiscal orthodoxy) to the electorate, by adopting less controversial policies: for instance, by scrapping a commitment to introducing a 50 per cent income tax rate for those earning over $£ 100,000$. Internal policy debates over the renewal of the nuclear deterrent Trident and over tuition fees have highlighted current divisions within the wider party. These divisions are partially a result of the party's constitution, which allows grassroots activists a degree of influence over the leadership and ideological positioning of the party. ${ }^{27}$ Furthermore, ideological differences based upon a socialclassical liberal divide also aggravate tensions. This is illustrated by the recent publication of two very different ideologically motivated books by parliamentarians and senior party activists. $^{28}$ The party has a federal, bottom-up organizational structure which allows party activists and members the opportunity to participate in the policymaking process. While their commitment to community politics, best illustrated through their successful campaigning methods, would once have set them apart, their strategies and emphasis on localism have now largely been adopted by the other main parties. However, the Liberal Democrats remain a clearly less hierarchical and centralized party than the Labour and Conservative parties.

26 J. Ashe, R. Campbell, S. Childs and E. Evans “"Stand by your Man”: Women's Political Recruitment at the 2010 General Election', British Politics, vol. 5 no. 4 (2010), pp. 455-80.

27 E. Evans, Gender and the Liberal Democrats: Representing Women? (Manchester: Manchester University Press, 2011).

28 See the economically liberal P. Marshall and D. Laws (eds), The Orange Book: Reclaiming Liberalism (London: Profile Books, 2004), and the socially liberal D. Brack, R .S. Grayson and D. Howarth (eds), Reinventing the State: Social Liberalism for the 21st Century (London: Politico's, 2007). 
One of the key challenges facing the Liberal Democrats has been overcoming the 'wasted vote' syndrome. ${ }^{29}$ For the third party in an ostensibly two-party system the Liberal Democrats have had to develop a more effective targeting strategy, focusing their attention and limited resources on seats where they stand the best chance of winning. In 2005, and despite the adoption of popular policies such as their opposition to tuition fees and to the war in Iraq, the party was unable to make much headway. Post-2005 therefore, there was a perception, both internally and externally, that the party had missed an important opportunity to make a significant electoral breakthrough. Following the 2005 general election there followed two leadership contests in quick succession, which generated a degree of instability within the Liberal Democrats. Indeed, the rapid change of personnel at the top of the party, coupled with a raft of damaging headlines regarding the personal lives of senior politicians, have made selling the party a much harder task.

Despite the distinctive organizational ethic discussed above, the Liberal Democrats have undergone a process of professionalization, in terms of both their organization and the image they present to the electorate. ${ }^{30}$ This professionalization can be illustrated by the increasing centralization of decision-making processes within the party and the erosion of grassroots influence. One way in which the Liberal Democrats have tried to be more electorally competitive is by making the party organization run more efficiently, with more direction from party headquarters. This process has been a key development within the party and has aided its attempts to present a credible image: investment in opinion research and the steadily increasing influence of the party leadership are two important ways in which the party has attempted to strengthen its position in British politics. It is therefore within the context of an increasingly compliant membership, dovetailed with an increasingly centralized party, that Nick Clegg was able to lead his party into a coalition government with the Conservatives. ${ }^{31}$

In the immediate aftermath of the 2010 general election, Nick Clegg stuck to his preelection pledge to allow the party with the biggest mandate to first seek to form a government. Luckily for the Liberal Democrats, the Conservatives secured both the highest percentage share of the vote and the highest number of seats, meaning that the party did not have to decide what actually constituted the 'biggest mandate'. Although a few meetings were held with Labour politicians, some senior Labour figures had warned against a coalition deal. Consequently, negotiations with the Conservatives moved on apace, with frequent discussions between David Cameron and Nick Clegg underpinning the formal negotiation process led by teams of senior politicians from both parties. ${ }^{32}$

29 A. Russell and E. Fieldhouse, Neither Left nor Right: The Liberal Democrats and the Electorate (Manchester: Manchester University Press, 2005).

30 E. Evans and E Sanderson-Nash, 'From Suits to Sandals: Professionalisation, Coalition and the Liberal Democrats', British Journal of Politics and International Relations, forthcoming 2011.

31 Evans and Sanderson-Nash, 'From Suits to Sandals'.

32 For an insider's account of the coalition negotiation process see D. Laws. 22 Days in May: The Birth of the Lib Dem-Conservative Coalition (London: Biteback, 2010). Additionally, R. Wilson, 5 Days to Power (London: Biteback, 2010), offers a more studied assessment of the process by drawing on interviews undertaken with critical actors across all three parties. 
For at least two years after the 2010 general election the assumption had been that the Conservatives would secure enough seats to govern as a single party. ${ }^{33}$ However, those involved with the coalition process have noted that occasional discussions between the Conservatives and Liberal Democrats had been underway prior to the election. Moreover, Nick Clegg had secretly asked a group of senior MPs in 2009 to start preparing for a hung parliament. ${ }^{34}$ It is to the coalition negotiations and subsequent policy gains and losses that this article now turns in order to explore the likely impact of the coalition on both parties' fortunes.

\section{From negotiation to government}

Despite wanting to distance himself from talking about possible coalitions during the election campaign, it was Nick Clegg's Liberal Democrats who were best prepared to deal with the coalition negotiation process. Clegg's team had produced two different policy documents, one that would be used for full coalition negotiations and one for use in a supply and confidence arrangement. ${ }^{35}$ Crucially, Clegg had asked his team to prepare documents that would work with either party, and at no point, according to Laws, did the leader express a preference for working with one party or another, although he was publicly critical of Brown. ${ }^{36}$ However, various accounts of the negotiation process, and also the Liberal Democrats' preparations for a hung parliament, highlight that in fact the party was much more prepared to enter into an arrangement with the Conservatives than with Labour. ${ }^{37}$ Moreover, the Liberal Democrats got the clear impression that Labour was simply not interested in forming a coalition government, despite the shared heritage of the parties on the centre-left. ${ }^{38}$ This perception was underscored by the fact that Labour entered into talks with the Liberal Democrats without a formal negotiation document or strategy. ${ }^{39}$

While the negotiating teams for both the Liberal Democrats and the Conservatives were made up of senior politicians and did not include the two leaders, it is clear that good inter-personal relations and various social links meant that the two had a lot in common. Both Cameron and Clegg had similar backgrounds, having attended fee-paying schools and Oxbridge, both had young families, and both professed themselves keen to usher in a 'new style of politics'. It would be foolish to overstate the importance of these personal similarities, but the fact that they obviously liked and respected each other undoubtedly offered a boost to the coalition negotiation process. Furthermore, the poor relationship that existed between Clegg and Brown served to underline the difficulty the Liberal Democrats would have working with Labour under Brown. ${ }^{40}$ The Conservative

33 P. Norton, 'The Politics of Coalition', in Allen and Bartle, Britain at the Polls 2010, pp. 242-65.

34 Laws, 22 Days in May, p. 13.

35 Kavanagh and Cowley, The British General Election of 2010, p. 205.

36 Laws, 22 Days in May, p. 13.

37 Wilson, 5 Days to Power, p. 36.

38 Kavanagh and Cowley, The British General Election of 2010, p. 216.

39 Wilson, 5 Days to Power, p. 32.

40 Wilson, 5 Days to Power, p. 34. 
negotiating team also took the Liberal Democrats seriously. Indeed, the coalition negotiations saw a surprising amount of goodwill and common ground between the two teams, each of which included spokespersons for the various wings of each party.

Each negotiation team had clear red lines. For the Conservatives this included the fiscal policy of taking immediate action to reduce the deficit and oppose any further transfer of sovereignty from Westminster to Brussels. For the Liberal Democrats political reform, including a change to the voting system, was key. There was a surprising amount of consensus between the parties on economic policy, despite the fact that during the election the Liberal Democrats had adopted an approach more akin to Labour in terms of the scale and speed of deficit reduction. Moreover, the two parties were in agreement over the civil liberties agenda. Despite Conservative hostility to electoral reform, David Cameron demonstrated his commitment to achieving a full coalition with the Liberal Democrats by agreeing to hold a referendum on the Alternative Vote (AV) electoral system. ${ }^{41}$ This offer was an important moment in the coalition negotiations. The coalition agreement itself contained few other key concessions to the Liberal Democrats, although other significant policy wins included: restoring the earnings link for the basic state pension, with a 'triple guarantee' that pensions would be indexed to the higher of average earnings or prices; and a 'Great Repeal Bill' to reverse many of the Labour government's policies surrounding security and civil liberties.

In addition to securing the much-prized referendum on electoral reform, the Liberal Democrats' other significant gain was the number of government posts it received. Partly as a result of his strong performance in the television debates, but also surely as a result of his good relationship with Cameron, Nick Clegg was appointed Deputy Prime Minister. In addition a further four Liberal Democrats were given cabinet positions, with portfolios including environment, business and innovation, the Scottish department, and the key post of Chief Secretary to the Treasury. Each government department also contained a Liberal Democrat minister in order to ensure that neither party solely controlled a department. The party had won only 57 seats but almost half of its MPs now found themselves in cabinet.

For each leader presenting the coalition agreement to his party, securing support of all wings was critical in order to avoid embarrassing displays of internal dissent. For the Liberal Democrats this did not prove to be a significant issue, with only a small amount of public criticism from former leader Charles Kennedy. For the Conservatives, many of their backbenchers felt a keen sense of frustration, not least because they felt they had been bounced into accepting a referendum on the electoral system, but also because many of those hoping for government positions were acutely aware that these posts would instead be going to their new coalition partners. There was also a suspicion that Cameron was happier with the coalition than he would have been with a Conservative majority because of its potential to counter the party's right wing.

41 Just like FPTP, the AV electoral system is used to elect one member of parliament, but voters are given the opportunity to rank their preferences for candidates. In the event that no one candidate gets over 50 per cent of the vote, the votes cast for the candidate with the fewest number of votes are redistributed according to voters' second choice, and so on until one candidate emerges with the necessary 50 per cent. 
Table 3. Public support for party by month (\%)

\begin{tabular}{lccc}
\hline Date $(\mathrm{d} / \mathrm{m} / \mathrm{yy})$ & Conservative & Lib. Dem & Labour \\
\hline $2 / 2 / 11$ & 39 & 8 & 44 \\
$5 / 1 / 11$ & 40 & 8 & 42 \\
$3 / 12 / 10$ & 40 & 11 & 40 \\
$3 / 11 / 10$ & 41 & 11 & 40 \\
$3 / 10 / 10$ & 39 & 11 & 41 \\
$3 / 9 / 10$ & 42 & 12 & 37 \\
$3 / 8 / 10$ & 42 & 12 & 38 \\
$4 / 7 / 10$ & 41 & 16 & 36 \\
$13 / 6 / 10$ & 40 & 18 & 32 \\
$23 / 5 / 10$ & 39 & 21 & 32 \\
$6 / 5 / 10$ & 35 & 28 & 28 \\
$3 / 5 / 10$ & 34 & 29 & 28 \\
\hline
\end{tabular}

Source: Data taken from BBC Poll of Polls, available at: www.bbc.co.uk/news/uk-politics-10963393. Note that the election was held on 6 May 2010.

Almost a year on from the election the winners of the coalition arrangement seem to be the major parties. Despite the relative absence of any visible Labour opposition for the first few months of the government (they were distracted by a lengthy leadership contest to replace Gordon Brown), the party has had to do very little but soak up the support of those angry with the coalition programme. And for the Conservatives being the senior partner in a coalition government presiding over cuts of up to six billion pounds has, remarkably, not yet seriously dented their levels of support (see Table 3). Conversely, the Liberal Democrats have witnessed a steady decline of support since the coalition formation.

In addition to maintaining public support, Cameron has also managed to avoid inter-party tensions by making relatively few policy concessions. Indeed, even unpopular legislation, such as the right of prisoners to vote - the result of a directive from the European Court of Human Rights - has actually enabled both front- and backbench Conservative parliamentarians to unite in opposition to the ruling, with Cameron urging his backbenchers to vote against the government. ${ }^{43}$ Moreover, following the anger among backbenchers regarding selling off the forests of England, the government has performed a U-turn on the policy, thereby maintaining party cohesion. On the other hand, life in government has not been easy for the Liberal Democrats, who have faced a series of policy dilemmas that have divided the party.

The first real test for the Liberal Democrats came with the emergency budget. Contained within it was a commitment to increasing the rate of value added tax (VAT) from 17.5 per cent to 20 per cent. Despite the fact that during the election none of the

43 See M. Hall, 'David Cameron Urges MPs to Block Jail Vote Plan', Daily Express, 5 February 2011. 
parties explicitly ruled out a rise in VAT, the Liberal Democrats had made much of the likely VAT 'tax bomb' that would occur under a Conservative government. This proved to be embarrassing for the Liberal Democrats, with the Business Secretary Vince Cable forced to concede that the party had used the issue to 'score points' during the election. ${ }^{44}$ Despite the reservations of many within the party, in the end only two Liberal Democrat MPs voted against the tax rise, although four abstained.

Without doubt it is the issue of tuition fees for university students that has presented the greatest challenge for the Liberal Democrats thus far. The Liberal Democrats had campaigned on a specific pledge not to increase tuition fees and to work towards abolishing them altogether. The previous Labour government had established a commission to look into the funding of higher education and it was widely anticipated that the report would recommend that universities should be allowed to increase their fees substantially. Accordingly, the coalition agreement stated that Liberal Democrat parliamentarians would be free to abstain on any vote rather than vote for any proposal that they 'cannot accept ${ }^{\text {' }}{ }^{45}$ However, the Liberal Democrats actually split three ways during the vote, with government ministers supporting it, 21 backbench MPs voting against it, and eight abstaining. The impact of this controversial policy, and more specifically the very public backtracking on a specific pledge made less than a year beforehand, is difficult to gauge. However, regular student protests and images of burning effigies of Nick Clegg, coupled with a sharp drop in support for the Liberal Democrats in opinion polls towards the end of 2010, suggests that the party is, at least in the short term, bearing the brunt of public anger.

\section{Permanent coalition?}

Just under a year after the election it is too early to tell if UK voters have taken to the idea of coalition government. Early polls suggested that the public approved of the coalition programme, yet polling has also highlighted a deep mistrust of the cuts to public services and scepticism regarding the private-sector-led recovery. ${ }^{46}$ Although the next general election is not until 2015, there has been almost constant speculation that the Conservatives and Liberal Democrats will put up joint coalition candidates. The idea of permanent coalition is also underpinned by the electoral system: even if the electoral referendum rejects $\mathrm{AV}$, research has already demonstrated that the chances of a hung parliament under the current system remain high. ${ }^{47}$

Notwithstanding the failure of the FPTP system to deliver an overall majority, a positive result for the AV campaign might suggest support for the idea of coalition

44 See K. Walker, 'Vince Cable Admits Previously Opposing VAT Rise to "Score Points", Daily Mail, 28 June 2010.

45 Coalition Agreement, available at: www.direct.gov.uk/prod_consum_dg/groups/dg digitalassets/@dg/@en/documents/digitalasset/dg_187876.pdf.

46 Ipsos Mori End of Year Political Review, available at: https://kucahtkh.kingston.ac.uk/owa/ redir.aspx?C=3a29dae6fb1d43c5bc499eace8c36d39\&URL=http\%3a\%2f\%2fwww.ipsos-mori. com\%2fAssets\%2fDocs\%2fNews\%2fIpsos_MORI_End_of_Year_Review.pdf.

47 Curtice, 'So What Went Wrong with the Electoral System?', p. 637. 
government. The implications of a switch to AV are, however, far from clear. While the Conservatives have traditionally opposed any change to a more proportional electoral system, fearing an anti-Conservative tactical alliance, five years of coalition with the Liberal Democrats might facilitate the creation of an anti-Labour alliance. When asked about second preferences prior to the election, two-thirds of Labour voters said they would transfer to the Liberal Democrats. However, a month after the coalition was formed this had dropped to just one-third. Meanwhile, ahead of the election around half of Conservative voters said they would give the Liberal Democrats their second preferences and this remains largely unchanged. ${ }^{48}$ The Liberal Democrats split roughly evenly in terms of second preferences, meaning AV would be of little use in determining marginal contests between the two main parties.

In addition to potential reforms to the electoral system, the coalition government is also planning to reduce the number of constituencies from 650 to 600 . In doing so, constituencies will be more equal in terms of the number of constituents, but the decision to redraw nearly all of the boundaries has been criticized in a Commons report for being an overtly political move designed by the coalition to abolish mainly Labour-held seats. For instance, there will be a 25 per cent reduction in the number of Welsh seats and Wales as a nation predominantly votes Labour. ${ }^{49}$ The impact of reducing the number of seats on the overall chances of achieving a hung parliament may be small, but inevitably a reduction in the number of seats means that competition in those seats will increase. Thus a coalition agreement to field only one candidate in Labour-held seats could well prove an important strategy in securing a second term for the coalition.

Future electoral success for the Liberal Democrats lies in their ability to preserve their distinctive identity. Indeed, a danger facing the Liberal Democrats is that they become like Germany's Free Democrat Party (FDP) whose election campaigns often revolve around who they will seek to form a coalition with. Based on his responses to questions of this sort during the 2010 election campaign, this is something that Nick Clegg will wish to avoid. ${ }^{50}$ Many within the party are clearly pleased with the coalition agreement and with the opportunity to implement some Liberal Democrat policies, but whether or not they are able to convince the electorate, let alone their own activists, that they are sufficiently different from either main party will be key. There are many within the party who maintain the historical preference for electoral cooperation with Labour. ${ }^{51}$

The ties between Labour and the Liberal Democrats are, broadly speaking, rooted in an ideological commitment to progressive centre-left politics. Connections between the two have also been underpinned by a sense of shared history: for instance, the Lib-Lab

48 A. Wells, 'How Would an Election Look Tomorrow under the Alternative Vote System?', available at: http://today.yougov.co.uk/commentaries/guest/how-would-election-tomorrowlook-under-alternative-vote.

49 Welsh Affairs Committee, 'The Implications for Wales of the Government's Proposals on Constitutional Reform', available at: www.publications.parliament.uk/pa/cm201011/ cmselect/cmwelaf/495/49502.htm.

50 See Laws, 22 Days in May.

51 N. Lawson and R. S. Grayson. 'Lab and Lib: A Dream Team', The Guardian, 9 May 2010. 
Pact of the 1970s and the close relationship between Tony Blair and Liberal Democrat leader Paddy Ashdown in the late 1990s. Notwithstanding these links, the two parties are of course electoral competitors. Indeed, one of the strategic assumptions made during the formation of the Liberal Democrats was that the new party would come to replace Labour as the main opposition to the Conservatives, just as it had been Labour's intention to replace the Liberals at the beginning of the twentieth century. ${ }^{52}$ The experience of participating in coalition government with Labour at sub-national level, and their experiences at the local level, signal that the party has been able to negotiate the difficulties associated with political partnerships. However, the extent to which the coalition with the Conservatives will cause long-lasting damage to the party's electoral prospects remains uncertain.

Options for the Conservative Party are much clearer: the pursuit of single-party government or another coalition with the Liberal Democrats. It is difficult to conceive of a grand coalition between the two largest parties despite the shift towards centripetal campaigning, given the adversarial nature of UK politics and the arithmetic. Interestingly, although most Conservatives would have preferred a Conservative government to a coalition, there have been suggestions from Conservatives that the party should fight on a coalition ticket at the next general election. ${ }^{53}$ Indeed, despite noting the differences between the two parties Conservative MP Nick Boles has observed shared commons values, including an emphasis on individualism, localism and economic liberalism. ${ }^{54}$

Despite plummeting opinion poll ratings it is clear that the Liberal Democrats have most to gain from the UK shifting from a one-party to coalition government. However, therein lies the problem. Given the current levels of public hostility towards the party, many perceive the role of Nick Clegg as permanent kingmaker as deeply undemocratic. ${ }^{55}$ Moreover, it is difficult to see how Clegg could work with Labour in office after serving as Deputy Prime Minister in a Conservative-led administration. This last point is particularly important - in truth it is difficult to see Labour wanting to enter into any future coalitions whilst Clegg is still leader of the Liberal Democrats.

\section{Conclusion}

This article has considered and assessed the impact of the coalition on the political parties involved. For the Conservatives, despite the disappointment of not securing an overall majority, the coalition has brought about surprising benefits. In the first instance their coalition partners appear to be the subject of most of the public hostility regarding the cuts. Indeed, prior to the election the then Shadow Chancellor George Osborne had joked that he would be the most hated person in Britain when the cuts started to hit. This role has now shifted to Nick Clegg, whom many on the left perceive as having

52 Russell and Fieldhouse, Neither Left nor Right, p. 39.

53 See N. Boles, Which Way's Up? (London: Biteback, 2010).

54 Boles, Which Way's Up?, p. xviii.

55 See, for instance, the No2AV campaign which is using Clegg's unpopularity as a key plank of their opposition to a change to the electoral system: www.no2av.org. 
betrayed his principles, notably over tuition fees, in order to secure power. Participating in coalition government with the Conservatives has undoubtedly been a gamble for the Liberal Democrats. On the one hand, the party is able to point to specific policy wins, such as the change to the electoral system if the result of the referendum is in favour of AV; conversely, breaking their pledge on tuition fees has further eroded trust in politicians, notably among the younger generation.

It is these issues of trust and faith in the democratic process that many commentators cite as being one of the most significant legacies of the Liberal Democrats' participation in this government. Indeed, breaking specific pledges such those over tuition fees has the potential to do greater damage to the Liberal Democrat share of the vote, notably in university towns, than severe Conservative-driven cuts in public spending. While the two parties between them garnered a higher share of the vote (59.1 per cent), concerns regarding the specific mandate of the coalition agreement versus the very different election manifestos that each party fought the election on, have raised questions regarding the legitimacy of elite-led coalitions.

In conclusion it is clear that each party has benefited to a certain extent. Both party leaders have undertaken a modernization process within their parties, and one of the benefits of coalition is to safely sideline their more extreme wings. This is important in terms of executive dominance of the legislature and also has significant ramifications for inter-party democracy, with increasing power for the leadership. Additionally, the rhetoric surrounding the idea of 'working together in the national interest' inevitably allows the leaders to point to a 'new style of politics'. However, the dramatic drop in support for the Liberal Democrats, coupled with a U-turn on the totemic issue of tuition fees and continued high approval ratings for Cameron, suggests that the Conservatives have thus far gained more from the arrangement than the Liberal Democrats. Given that the Conservatives have always been in favour of one-party government, it is ironic that it is they, rather than the Liberal Democrats, who always favoured multi-party governance, who appear to have benefited most from coalition politics.

\section{Biographical note}

Elizabeth Evans is a Lecturer in Politics at Kingston University London, and is the author of Gender and the Liberal Democrats (2011). Her research interests include representation, political parties and elections, and she has published in the British Journal of Politics and International Relations, Parliamentary Affairs, the Journal of Legislative Studies, British Politics and The Political Quarterly. 